Review

\title{
Cross-country evidence for social dimensions of urban water consumption during droughts ${ }^{\text {th }}$
}

\author{
John Milton Asprilla Echeverría \\ School of Social and Behavioral Sciences, Faculty of Public Administration, Erasmus University Rotterdam, Burgemeester Oudlaan,50, T17-10 (17th floor),
} Mandeville Building, 3062, PA, Rotterdam, the Netherlands

\section{A R T I C L E I N F O}

\section{Article history:}

Received 26 June 2019

Received in revised form

1 March 2020

Accepted 2 March 2020

Available online 6 March 2020

Handling Editor: Prof. Jiri Jaromir Klemeš

\section{Keywords:}

Water pricing

Droughts

Water scarcity

Water consumption

Behaviors

Sustainability

\begin{abstract}
A B S T R A C T
A systematic literature review is carried out to understand the social dimensions driving the adoption of water saving behaviors in urban households. Salient aspects of the problem correspond to price elasticity of water demand, citizens' awareness of water value and water conservation intentions, the management of which is generally tackled through water price and non-price approaches. However, the evidence falls short to explain the social drivers and inhibitors of stable water consumption reductions. After reviewing 65 papers documenting research conducted in North America, Australia, United Kingdom, Middle East, Mexico, China and Japan, a series of categories of analysis drawn from the literature are introduced as the social factors that influence water conservation reduction. Although the brink of the state of the art mentions the existence of an intention - behavior gap, sustainability requires further aspirations than short-term water consumption reduction by households. The long-term challenges of sustainability require the understanding of intention - behavior - stable reduction gaps. Further research is needed to fill this double gap. Understanding the determinants and insights behind the dissipation (or stabilization) of water consumption reductions through time are certainly rich areas of analysis for the social sciences. (C) 2020 Published by Elsevier Ltd. This is an open access article under the CC BY-NC-ND license (http:// creativecommons.org/licenses/by-nc-nd/4.0/).
\end{abstract}

\section{Contents}

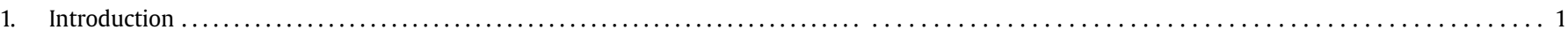

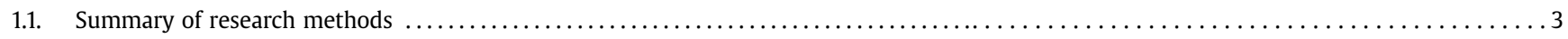

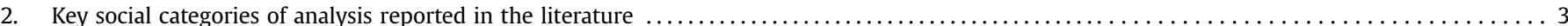

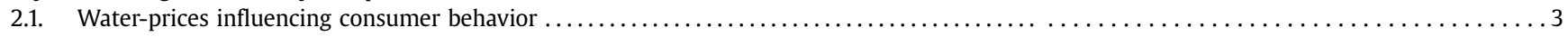

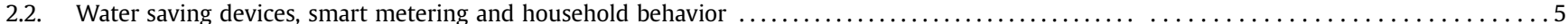

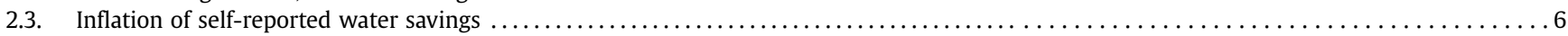

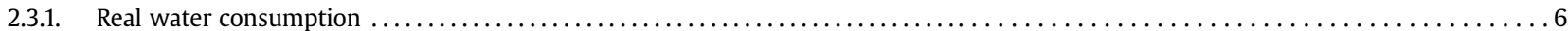

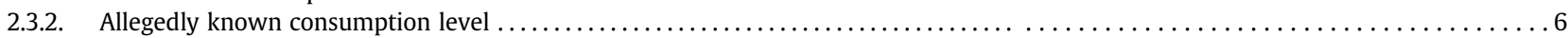

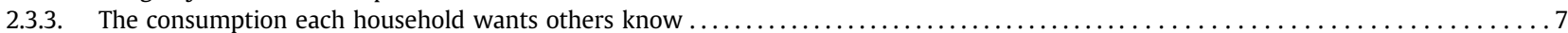

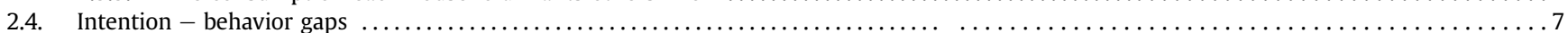

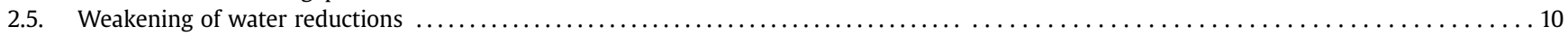

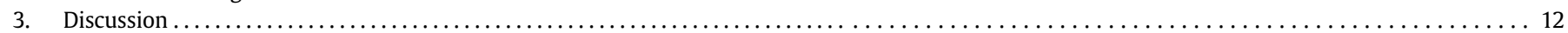

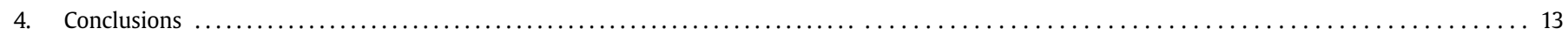

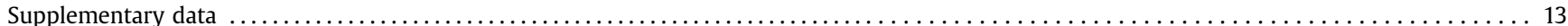

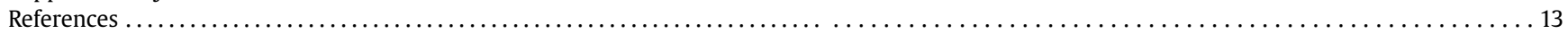

\footnotetext{
I am indebted to Professors Bart van Hoof and Wim Hafkamp for encouragement, comments and suggestions in preparing this article. This work was supported by the Department of Science and Technology of Colombia through the research scholarship grant number 789-2017.

E-mail address: jasprilla@javeriana.edu.co.
}

\section{Introduction}

Beyond water demand price elasticity at the household level (demand shifts relative to changes in water price), citizens' 
awareness of water value and their expressed intention to conserve water, the evidence falls short to explain the social drivers and inhibitors of stable reductions in water consumption after the implementation of water price and non-price approaches and other management strategies.

Water management refers to the dynamic and adaptive process of matching the relation between water availability and the needs of households, communities and other stakeholders, as evaluated in terms of quantity and quality through space and time (Chartzoulakis and Bertaki, 2015). The adoption of water management practices comprises social behavior, technical and legal issues, institutional settings and users' habits. Said implementation is intended to ensure the equitable operation and optimum usage of existing water systems (Chartzoulakis and Bertaki, 2015; Nyamwanza and Kujinga, 2017).

Water conservation and drought conditions are closely intermingled. The conservation strategy is aimed at guaranteeing a sustainable administration of this resource, combating scarcity issues and considering both the demand and source sides of the problem (Aprile and Fiorillo, 2017). Water conservation is a matter of attitudes and behavior for the benefit of indoor consumption (Randolph and Troy, 2008). In this regard, conservation theoretical underpinnings come from the environmental sciences (Aprile and Fiorillo, 2017).

Provided that, on the one hand, water demand has grown and, on the other hand, climate change, drought conditions and water quality issues are exacerbating the risks of running out of water in different regions (Abdulrazzak and Khan, 1990; Balling et al., 2008), water scarcity has actually replaced abundance (Zetland, 2011). Emerging threats to water security have occurred in Rome, Italy, and Cape Town, South Africa (World Bank, 2018). Particularly, water table declination and droughts are pervasive in Western USA, Mexico, Iran, Jordan, North Africa, Iran, India, parts of China and other areas in South Asia (World Bank, 2018).

Local planning is faced with guaranteeing the satisfaction of water demand via increased supply, the promotion of water conservation or the reduction of consumption by stakeholders. Supply augmentation and infrastructure enhancement are lately becoming limited due to rising costs (Abdulrazzak and Khan, 1990; Russell et al., 2007; Katz et al., 2016), ${ }^{1}$ pollution of water sources (Russell et al., 2007; Salameh, 2008), reduction of aquifer stocks, climate change projections of drier summers (Watson, 2017) and reduced precipitation levels, with their consequent impact on the replenishment of water reserves.

Supply alternatives include desalination plants, reservoir capacity amplification, drilling of new wells and deepening of existing ones, enhancement of freshwater treatment capacity, fixing of outpouring pipes, and other engineering solutions.

The desalination of seawater has been contemplated as a primary supply augmentation option. However, due to its high costs, policymakers have encouraged the more cost-effective demand

\footnotetext{
1 (Abdulrazzak and Khan, 1990) perform a comparative review on the relative costs of consumer-oriented domestic water conservation practices, authors highlight the high costs of pricing and rationing as a conservation strategy which basically result effective under enforcement schemes. In addition to this, findings for Saudi Arabia has been realized, that desalinization does not represent a viable, long-term water source because of the high costs associated with desalinization technology and long-distance conveyance (Russell et al., 2007). underscore that Tunisia and Morocco are attempting to charge irrigators an amount designed to at least cover the average cost of delivery of the water (Katz et al., 2016). make a comparison between demand management oriented policies such as pricing and campaigning and supply management options such as desalinization in Israel and find that messaging may lead to a savings of nearly 1.2 cubic meters per household for the five week period, which is more cost-effective than the cost of supplying additional water via desalination.
}

management options (Katz et al., 2016). These alternatives include water price increase, subsidies granted for attaching to low-flow pipelines, seasonal restrictions of water use and awareness-rising campaigns (Berk et al., 1993; Katz et al., 2016; Lowe et al., 2014). ${ }^{2}$

In order to achieve sustainable water management, current discussions are no longer focusing on either supply enhancement or demand management, but on a thorough understanding of demand drivers and the social dimensions of water conservation. Spending resources exclusively on supply improvement improperly incentivizes consumption, in the sense that it strengthens the perception of unlimited supply solutions, with disregard for consumption patterns or water use perceptions. Thinking beyond supply enhancement, price increases or mandatory restrictions has become a must when it comes to water sustainability (Lowe et al., 2014).

Across different countries, price and non-price management approaches have been implemented to curb water demand (Renwick et al., 1998). Pricing policies have received much attention by economists who consider the price to be the best instrument to induce water conservation. They consider that the welfare loss implied in water restrictions (such as supply interruption) usually exceeds that of price increase (Millock and Nauges, 2010; Roibás et al., 2007).

In the field of water management, non-price approaches to conservation require voluntary implementation and straightforward compliance to restrictions. They usually ask and encourage consumers to adopt recommended consumption patterns and attitudes, together with the use of technological devices. Furthermore, non-price strategies expect consumers to voluntarily consume less water both in-doors and out-doors. The problem with the voluntary adoption of prescribed behaviors lies on the risk of not sufficiently encouraging people to curb water consumption patterns, which may threaten the sustainability of water provision.

Different advocates of pricing policies argue that this strategy is an adequate mechanism to signal scarcity. Water price rising during low precipitation periods is expected to lead consumers to use less water by either decreasing or removing habitual usages, depending on individual preferences (Olmstead and Stavins, 2009; Renwick and Green, 2000).

Notwithstanding, price as a driving mechanism to reach water conservation depends on key issues such as the different aspects of demand price elasticity. At the household level, this parameter is usually around -0.51 (Olmstead and Stavins, 2009), which represents an inelastic water demand. This technically means that demand changes are less than proportional to price increases. The economic theory states different reasons to explain the price inelasticity of urban water demand: (1) there are not very similar substitutes for different water uses; (2) the water bill share tends to be small with respect to the usual domestic budget; and (3) water demand is complementary to that of other goods (Renwick et al., 1998). A primary implication of water demand price inelasticity is the need for considerable price raises (which tend to be politically

\footnotetext{
2 (Berk et al., 1993) show how households in the Los Angeles and Bay areas reduced their water consumption through a variety of mechanisms. Reductions in water consumption were mostly driven by acquisition of new technology, restrictions to outdoor and indoor use and water pricing. The results of Katz et al. (2016), for Israel imply that price increases may be effective in achieving water conservation but are unlikely to have a long-term effect if the price is lowered. Conversely, conservation campaigns may be as effective as price increase in achieving water conservation and may also have a longer-term effect. In Australia (Lowe et al., 2014) found that a social marketing campaign has the potential to be a highly effective approach to changing use behaviors for household water consumers. However, in this case, social marketing was supported by other measures including restrictions and subsidies.
} 
unacceptable: Rodriguez-Sanchez et al., 2018) to attain substantial declines in water use (Katz et al., 2016).

For their part, non-price strategies may still provide feasible and cost-effective options to manage water demand (Katz et al., 2016) and curb its consumption. Non-price approaches include examples such as water saving campaigns; restrictions to outdoor water use; restrictions in periods of severe water scarcity; limitations to certain water targets per day. Through the incorporation of the social aspects of the problem, non-price approaches try to understand how the different elements of the water management system interact and integrate in the promotion of water conservation. This perspective constitutes an interrelated system that goes beyond price increase, which might be no more than a unidirectional and isolated element of the management system.

Based on the drawbacks of supply enhancement options, both water companies and public organisms have deviated their attention to water policies aimed at incentivizing demand behaviors as a better alternative, especially during drought conditions (Fielding et al., 2012; Martínez-Espiñeira and García-Valiñas, 2013). The present work precisely develops this point, mainly focusing on non-price water management strategies, as the author is acquainted with the potential of behavioral and social drivers when it comes to reaching sustainable levels of water consumption at the household level.

\subsection{Summary of research methods}

The current paper presents a systematic review of the social and behavioral dimensions of water conservation in urban areas of the world. It is built upon the revision of sixty-five articles published in peer-reviewed journals related to water, climate change, social and environmental psychology, pro-environmental behavior and ecological economics.

The time span covered by this review includes articles published from 1980 to 2018. To execute the analysis, the author summarized the key elements of each article in terms of the central tenets of the study, the findings, conclusions, methods, and the country in which the reviewed water management programs or policies were implemented. This systematic process allowed identifying the principal categories of analysis of the theories and characteristics of the social dimensions of water conservation.

Almost $50 \%$ of the reviewed water conservation research works were performed in Australia and the United States of America. In the USA, most studies came from California, Texas, Arizona and Atlanta. Middle East studies represent 10\% of the papers. Drought and climate variability are socio-environmental issues to solve in some of listed countries, for instance Australia and some parts of Western USA (see Fig. 1).

For each study, the most relevant information related to a thorough understanding of water conservation was extracted and classified. ${ }^{3}$ The main topics analyzed in this process included weather conditions and their examination, key policy drivers to promote water conservation, managers' and water users' perspectives, and main conservation challenges.

The leading research question of this review inquired about the key findings of the studied papers in terms of the social drivers of water conservation programs around the world.

\section{Key social categories of analysis reported in the literature}

Water conservation strategies have proved not to be a simple endeavor, neither in developing nor in developed countries, since

\footnotetext{
${ }^{3}$ The complete spread sheet is available upon request.
}

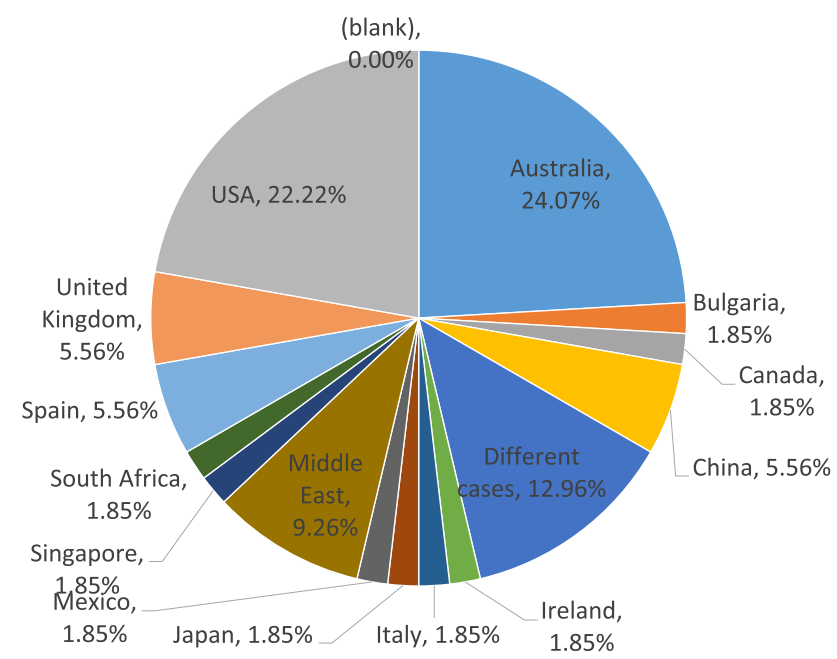

Fig. 1. Regions/countries in which different water management studies have been conducted.

Source: author's elaboration

they demand a thorough understanding of incentives, both psychological and economic, and of the type of information provided to households. This section introduces five categories of analysis drawn from the literature.

In pretending to achieve sustainable water consumption by households, current discussions no longer focus on supply enhancement or demand management, but on understanding the demand drivers and social dimensions of water conservation.

As water demand has grown, water scarcity has replaced abundance (Zetland, 2011), and climate change, drought conditions and water quality issues are exacerbating the risks of running out of water in different regions (Abdulrazzak and Khan, 1990; Balling et al., 2008). The option of increasing water supply is becoming much more limited due to water scarcity - which certainly rises the cost of supply enhancement - contamination of surface and groundwater sources and forecasted drier seasons in certain regions of the world (Abdulrazzak and Khan, 1990; Russell et al., 2007; Katz et al., 2016).

\subsection{Water-prices influencing consumer behavior}

The economic theory states that if water managers choose prices to maneuver water demand, the most important variable to understand is water price demand elasticity. This is due to the fact that a raise in the water price leads to a demand reduction, all else equal (Olmstead and Stavins, 2009). Notwithstanding, different studies have found a less than proportional response of water consumption

\footnotetext{
4 (Russell et al., 2007) suggest that a simple uniform emission charges applied across all sources and perhaps adjusted by trial and error will not produce given ambient quality standards at least resource cost. In addition to this, economic instruments for water quality context imply that attaining efficiency in any realistic situation-using emission charges or tradable rights-requires a great deal of information and the solution of an optimization (cost minimizing) model for the region at issue (Abdulrazzak and Khan, 1990). suggest that future demands will increase, unless severe policies are implemented to conserve water and adapt to the public to scarcity of their water resources; if demand increases, it will result in accelerated exploitation of groundwater, expansion of desalinization capacity, and generation of more wastewater, resulting increased costs. Countries categorized as chronic water scarce depending also on desalinization, are searching for more costeffective demand management options due to high costs of existing water sources (Katz et al., 2016).
} 
to price increase. This price inelasticity means that, e.g., a one percent raise in price provokes a less-than-one percent reduction in water consumption. This is, water users' reaction is less than proportional to price increase (Jehle and Reny, 2011; Renwick et al., 1998).

A further discussion on the price and non-price approaches to the promotion of water consumption reduction is referred to the need to substantially increase water fees and block rates. Advocates of increasing water prices argue that these reflect and signal the scarcity of the resource. The scarcer the resource, the higher the price of the fees paid by the consumers, because it is more expensive to collect the liquid from limited sources. Hence, either higher prices or scarcity surcharges come to rise the total price, thus reducing the demand and preventing shortage (Zetland, 2011).

In cases of water availability contraction, conservation is stimulated through commands or "moral suasion" instead of price raising (Collinge, 1994). This author reports on an efficient-pricing alternative developed to promote conservation without affecting distributional equity in San Antonio - Texas. There, a system of water coupons could be traded among water guzzlers and water frugal users by means of instruments of transferable rate entitlements.

In line with price increases and surcharges, a key issue is the baseline water price from which the increase may apply. Despite the fact that the money disbursed on the water bill is usually a comparatively minor portion of the household domestic expenses (Renwick et al., 1998), price increases have different effects on households according to income level, status and attitudes.

Price elasticity and other findings related to the effect of price on water use are presented in Table 1. In most of these studies, domestic water demand tends to be price inelastic due to its small comparative cost in the household consumption basket (see Table 2).

In some other cases, the water rates are too low to significantly curb consumption. Relevant cases show how charging flat water rates does not encourage conservation (Randolph and Troy, 2008; Van Vugt, 2001), as it has been observed in places like Australia and the United Kingdom. Charging increasing bills for higher water charges seems to decrease water use in comparison to applying flat fees. This variable tariff system provides a direct incentive for households to lessen consumption (Van Vugt, 2001).

We are currently facing cases of water fees ranging from low to very low to encourage conservation (Randolph and Troy, 2008). This implies almost no price for water with respect to its value and scarcity. It is assumed that such cheap prices were established in situations of abundance when water managers just delivered the liquid where it was needed, no matter the cost, because it was overflowing and easily accessible.

In terms of baseline water prices and income levels, households with lower income respond better and more positively to water charge increases when compared to richer household groups (Renwick et al., 1998). This is a relevant issue in most emerging countries, especially when considering that low-income households are a large share of the total.

Researchers that defend non-price approaches instead of pricing policies argue that augmenting the price of water might not be an efficient strategy to motivate water conservation when it comes to wealthy users, who may perceive price increase as a slight cost (Corral-Verdugo et al., 2012). However, even non-price approaches may prove useless in the case of affluent households.

The predictions of the influence of earnings are clearer when referring to water-saving practices. The opportunity cost of time for wealthier families might lead these households to perceive that water-saving habits alter their productivity. In contrast, lessaffluent households may be more willing to adjust their behavior to water conservation (Martínez-Espiñeira and García-Valiñas, 2013). Even though rich households may afford some costly water saving equipment, they may not value their contribution to water savings as low-income families do. This is explained by the diminished marginal utility of income that accompanies wealth (Millock and Nauges, 2010).

In addition to the negligibility of water prices and time opportunity cost, higher income households tend to be influenced by key subjective consumption drivers. High water consumption in middle-upper class and rich households is mediated by recreational reasons, lifestyle and status. At these social levels, using water at home is more than supplying basic domestic necessities, since it offers the possibility to keep a big, attractive, clean, and recreationcentered house that allows exhibiting social prestige (Harlan et al., 2009).

This type of result has been relevant in explaining out-door water use in Arizona, California and Australia. Phoenix dwellers consume much more water in comparison to a representative urban dweller. This is mostly due to outdoor activities, since the typical family consumes approximately $650,000 \mathrm{~L} / \mathrm{year}$. This mode of water usage is driven by irrigation schemes that prevail over temperature and rainfall conditions (Balling et al., 2008).

Keeping the economic value of a house is positively signaled by a leafy and good-looking garden which, as an indication of prestige in the neighborhood, may come to be more relevant than saving water

Table 1

Mechanisms involved in price inelasticity of water demand and substantial price raising.

\begin{tabular}{|c|c|}
\hline Key mechanisms found in the literature & Country/region \\
\hline $\begin{array}{l}\text { Price raising and water trading entitlements, rather than the implementation of non-price } \\
\text { strategies, are able to significantly decrease the economic burden of reaching water } \\
\text { consumption declination (Collinge, 1994; Olmstead and Stavins, 2009). }\end{array}$ & San Antonio - Texas \\
\hline $\begin{array}{l}\text { Increasing water tariffs according to consumption levels appears to allow better reactions than } \\
\text { those obtained when charging flat water tariffs. This variable tariff system provides a direct } \\
\text { incentive for households to reduce consumption (Van Vugt, 2001). }\end{array}$ & United Kingdom \\
\hline $\begin{array}{l}\text { More affluent family groups showed a weaker reaction to higher water prices than households } \\
\text { with lower income levels (Renwick et al., 1998). }\end{array}$ & Santa Barbara and Goleta - California \\
\hline $\begin{array}{l}\text { Water charges were too low to be an important driver of water consumption reduction. In } \\
\text { Sidney - Australia, the water charges were perceived as not being able to activate water } \\
\text { conservation (Randolph and Troy, 2008). }\end{array}$ & Sidney, Australia \\
\hline Substantial price increases due to demand inelasticity (Katz et al., 2016). & Israel. \\
\hline $\begin{array}{l}\text { Due to its small participation in the usual household budget, domestic water demand tends to } \\
\text { be price-inelastic in most cases (Renwick et al., 1998; Worthington and Hoffman, 2008). }\end{array}$ & $\begin{array}{l}\text { A survey of studies for Perth, Sidney in Australia, Arizona, Illinois, Texas in } \\
\text { USA, Kuwait, Hawaii, California, Spain, Indonesia, others. }\end{array}$ \\
\hline $\begin{array}{l}\text { Residential water demand is known to be price inelastic. Managers of water utilities have often } \\
\text { preferred to impose restrictions on water use instead of raising prices (Millock and Nauges, } \\
\text { 2010). }\end{array}$ & OECD countries \\
\hline
\end{tabular}


Table 2

Water saving devices and associated behaviors.

\begin{tabular}{|c|c|}
\hline Mechanisms found in the literature & Country/region \\
\hline Behavioral offsetting can undermine the effectiveness of water saving appliances (Fielding et al., 2012) & Queensland, Australia \\
\hline Water saving technologies produce less savings than expected (Renwick et al., 1998). & $\begin{array}{l}\text { Santa Barbara and Goleta - } \\
\text { California (USA) }\end{array}$ \\
\hline $\begin{array}{l}\text { Water savings resulting from water efficient appliances can be offset by behavioral changes prompted by the technology (Olmstead and } \\
\text { Stavins, 2009) }\end{array}$ & Different countries \\
\hline $\begin{array}{l}\text { Smart water initiatives remain somewhat blind to the complexity of cultural practices, subjectivities, dispositions, and affective } \\
\text { responses of customers when confronted with strategies intended to shift their attitudes and behaviors (Watson, 2017). }\end{array}$ & United Kingdom \\
\hline
\end{tabular}

(Harlan et al., 2009; Spinti et al., 2004). When people choose to live in big houses which involve using water-demanding artifacts, they are attributing water a simple-input affordance instead of considering it as a scarce and valuable resource (Harlan et al., 2009). In Southern Australia, families that belong to the greater group of consumers are aware of the elevated consumption trend on the part of those having large gardens that are weekly watered, which certainly surpasses water use frequency restrictions (Pearce et al., 2014).

Some cues indicate an apparent asymmetry between water fees and water availability. Thus, it is convenient to inquire about the connection between a no-longer-abundant water resource and its current low or flat rates, without expressing any preference for the price or non-price approaches. In this sense, it is important to analyze the way managers have administered the relation between the facilities to collect, treat and deliver water and the corresponding low or flat prices charged to consumers (Randolph and Troy, 2008; Van Vugt, 2001; Zetland, 2011). It can be reasonably assumed that the more difficult it is to collect and distribute fresh water, the more scarcity-awareness the consumers should express and the more collaborative they should they be in practicing conservation.

Water managers should probably contemplate their job from the perspective of water consumers, to step aside from their relative passiveness and become more cooperative partners in collectively reaching water conservation goals. Notwithstanding, the relation between been knowledgeable of water value and its corresponding conservation attitude is not straightforward (Jorgensen et al., 2009; Pearce et al., 2014).

Illustration 2-1 summarizes the price and non-price water demand management strategies. The main difference with respect to conventional policy approaches is that such assumed linearity between water use prescriptions and water users' abidance does not exist.

An additional issue refers to the extent to which any proposed substantial price increase may considerably affect the budget allocation of low-income households. There is general agreement on the redistributive and parity effects of significant water price increases (Grafton and Ward, 2008), and this affects both developing and developed countries, the latter being particularly sensitive through low-income households. In this regard, international organizations have called the attention to the fact that water is a human right. Taxes (e.g., VAT) form part of the water bill people receive, which ranges from zero to 28 percent. However, the discussions about human right to water resources deserve especial attention and fall out of this article aim.

In discussing the range of low to very low water prices, it is important to consider the differential marginal effects provoked by price augmentation, depending on the household budget share of water fees. If a price increase surpasses certain thresholds, doubts might be cast on the need to support the water charges of lowincome households. Potable water production and distribution costs tend to be rarely recovered via water fees, so this is usually attained by subsidizing the price (IWA, 2016).

\subsection{Water saving devices, smart metering and household behavior}

Considerable research has been devoted to estimating the effect of smart metering and water saving devices at the household level. This type of analysis has been almost exclusive for wealthy places such as Spain, United Kingdom, Sidney, South Wales, Queensland and Perth in Australia, and Colorado and California in the United States of America.

To the best of the author's knowledge, no studies have been conducted to estimate the effect of smart metering and water saving artifacts in developing countries. This might be strictly related to the lack of implementation of this technology to promote water conservation and management in these countries.

A smart meter is a piece of advanced equipment aimed at obtaining more accurate and sophisticated information on water consumption (Beal et al., 2013; Liu et al., 2016). Nowadays, technological progress allows families to get immediate information on water use (Seyranian et al., 2015). In comparison to conventional monthly metering, the modern smart water metering assists households in gathering water consumption statistics at a greater detail (Liu et al., 2015).

One of the main assumptions of smart metering research is that noticeable water consumption data can further encourage users to preserve the resource (Landon et al., 2018; Nguyen et al., 2018). ${ }^{5}$

In Switzerland and Spain, relevant projects have focused on stimulating water users to save water by means of "a sociotechnical information system", 6 which provides personalized feedback on water consumption (Novak et al., 2018).

The provision of innovative means to measure water consumption is a key stage towards urban water conservation. Notwithstanding, water consumption measurement by technological devices might be innocuous if water data is not provided and analyzed properly. For instance, in Australia, despite thorough data collection through smart equipment during summer and winter times, information feedback to households is limited (Liu et al., 2016).

Despite the technological attributes of water measuring, there are different social elements bridging smart metering and water conservation. The smart metering strategies implemented in the United Kingdom are still somewhat sightless with respect to the

\footnotetext{
5 (Nguyen et al., 2018) designed an intelligent water management system (Autoflow $\odot$ ) and tested it in Australia suggest that embracing digital technologies will let customers to continuously get updated and highly detailed water end use data provided through web and phone applications, which significantly enhance their awareness of consumption trends, providing them with the impetus to manage their demand.

${ }^{6}$ Examples include the web-based application has been deployed in Switzerland and Spain. Besides providing information on water consumed by households, it provides additional incentives such as household profile, achievements in savings, self-set goals, saving tips and a leader-board to let others compare with themselves consumption (Novak et al., 2018).
} 


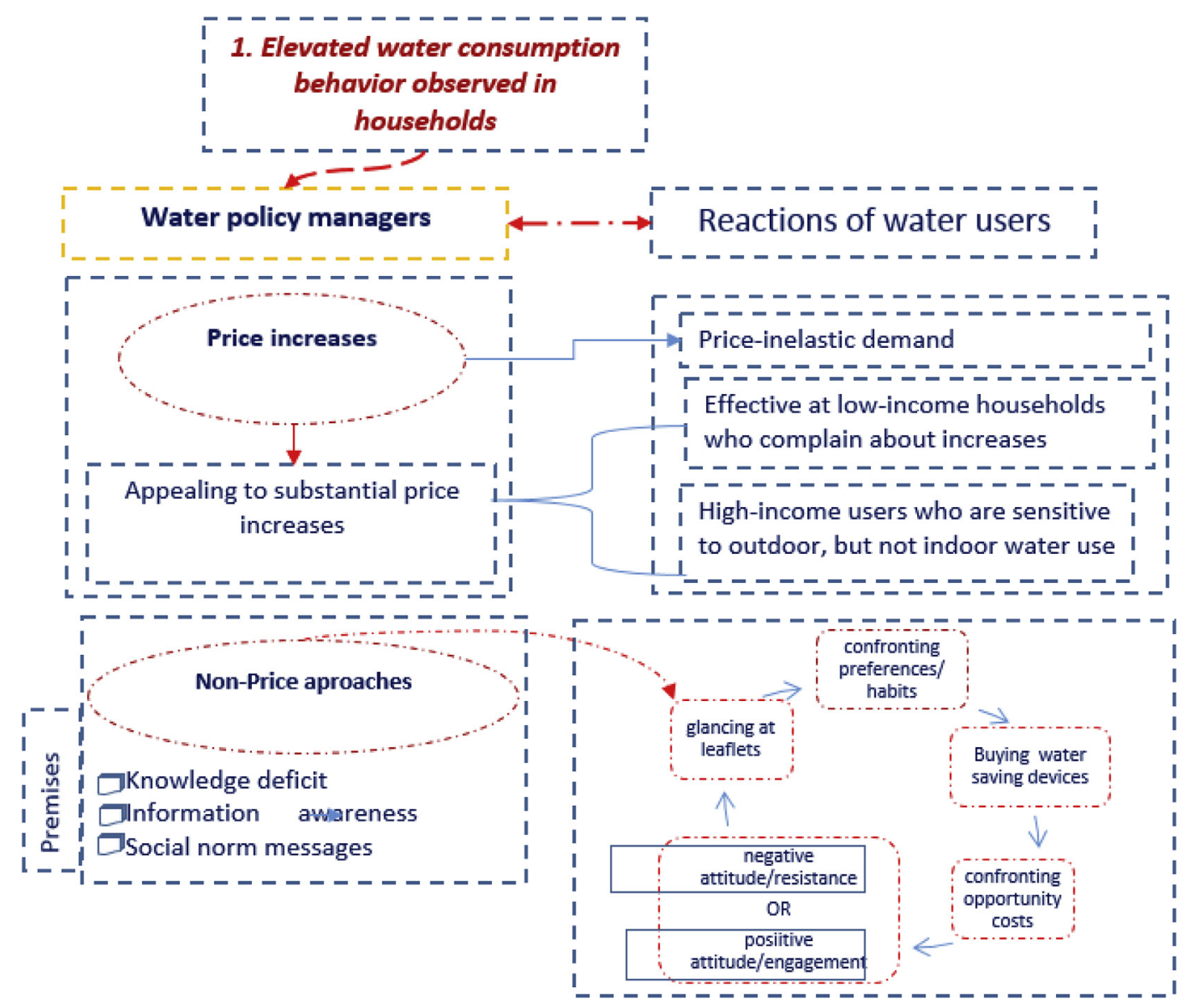

Illustration 2-1. Observed water conservation levels and water policy prescriptions. Source: author's elaboration

intricacy of cultural habits, biases, and emotional reactions of water users when confronted to alternative approaches aimed at modifying their behaviors (Watson, 2017). Olmstead and Stavins (2009) postulate that using water saving equipment not necessarily leads to consumption reduction because once the appliances are in use, they may activate behavioral variations that undermine water saving (Fielding et al., 2012; Olmstead and Stavins, 2009).

This offsetting arises because the users expect water efficient technology to effectively reduce consumption, which is probably interpreted as leeway to develop contrary behaviors (Fielding et al., 2012). Water saving devices should not be understood as an end in themselves, but as a mean to water reduction. Hence, the installation and some instructions about the benefits of saving the resource are not enough to reach real and sustainable reductions.

\subsection{Inflation of self-reported water savings}

Water conservation studies reveal the existence of discrepancies between three water consumption information levels. First, real water consumption; second, the consumption level allegedly known by households; and third, the consumption each household wants others to know.

\subsubsection{Real water consumption}

The real water consumption of potable water is widely variable, with large gaps across cities. Per capita household consumption ranges worldwide from 28 to $631 \mathrm{~L}$ per day, which is a 20 -fold variation. In 2014, the specific household water consumption in
Washington D.C. and New York was over 500 L/capita/day. Daily consumption records ranging from 200 to almost 400 L/capita/day (IWA, 2016) have been reported for different Japanese cities, the average Thai city, Perth - Australia, Puebla and Monterrey Mexico, different Chinese cities, and Los Angeles - California (USA) (listed in increasing order according to consumption records).

\subsubsection{Allegedly known consumption level}

Despite the elevated average water consumption observed in wealthy and developing countries, individuals do not exhibit complete knowledge and understanding about the consumption of this utility. Widespread unawareness of water consumption on the part of consumers has been reported in Sidney, Australia (Randolph and Troy, 2008) and China (Fan et al., 2013). In South-Queensland (Australia) there is a considerable knowledge gap about the role played by residential final water use (e.g., showers, washing machines, taps and toilets) in its biased assessment on the part of consumers (Beal et al., 2013; Liu et al., 2016).

Different reasons may explain why individuals lean towards ignoring their own consumption. In choosing to live in large houses with high water-use profiles, people in Arizona - USA are attuned to water as a good they pay for, while fewer understand it as a scarce and valuable resource (Harlan et al., 2009). Randolph and Troy (2008) argue that in Australia pricing controls may well be meaningless to raise awareness about water used by households.

In wealthy households, if awareness of the water pricing structure is low, cognizance of water consumption is expected to be correspondingly low (Harlan et al., 2009). In Sidney - Australia, one 
of the reasons why few people knew how much water they consumed were the numerous fixed fees included in the quarterly water bills, which actually mask the cost of water consumption and tend to reduce the relative significance of variation in seasonal consumption (Randolph and Troy, 2008).

Many water authorities provide information on how to read a water meter, expecting that knowledge of water consumption will assist users in conserving water. Determination of water consumption within a household, however, requires specific knowledge on how, where, when and who makes use of the utility (Willis et al., 2011).

The way administrators release and communicate the data generated from water meters has different effects on household water consumption. These data are usually released as social comparisons with standards, neighbors and other social norms.

One of the most popular and widely used social influence approaches to encourage behavior change is undoubtedly the use of social norms as part of information and feedback provision (Abrahamse and Steg, 2013). This is done instead of traditional approaches that attempt to promote conservation by appealing to environmental protection motives, financial goals or raw metering information provision (Fielding et al., 2013; Schultz et al., 2014). Social norms refer to the beliefs that individuals hold about what most of other people do or approve of doing Schultz et al. (2014).

In San Diego - California (USA), a comparative analysis was performed between information-only, ${ }^{7}$ descriptive norms ${ }^{8}$ and aligned norms. ${ }^{9}$ The tests of the information-only condition showed that providing tips about ways to save water did not produce a significant reduction in water consumption relative to a notreatment control (Schultz et al., 2014).

In Los Angeles (California, USA), a comparison of four different interventions to curb water consumption in an affluent neighborhood was developed. The results of the study suggested that, among heavy water consumers, those households exposed to information alone (knowledge deficit approach) exhibited the highest consumption levels both in the short and the long term, when compared to heavy water users in all other conditions (Seyranian et al., 2015).

In Queensland - Australia, Fielding et al. (2013) found that households who received descriptive norm information or water final use feedback showed a similar consumption pattern to that of the information only group. One reason for the effectiveness of the information-only approach may be recent experience of drought in the region. Hence, water conservation probably remained a salient and personally involving issue which led to consider water conservation activities as normative (Fielding et al., 2013). Similar arguments are provided by Berk et al. (1993), who suggest the importance of keeping in mind that, during the California droughts, there was a lot of publicity surrounding the drought and some evidence of palpable pressure to conserve.

\subsubsection{The consumption each household wants others know}

Water conservation social norms have a twofold effect. While they positively influence water conservation, they also motivate individuals to underreport their real consumption. The reporting of socially desirable water consumption may occur indistinctly during

\footnotetext{
${ }^{7}$ Households received tips on how to reduce water consumption (no normative feedback).

${ }^{8}$ Households received personalized information about their own water usage compared with the water usage of similar households in their neighborhood (descriptive message).

9 They received personalized information about their water usage as compared to similar households in their neighborhood, accompanied by a happy or sad face conveying social approval or disproval (descriptive and injunctive message).
}

periods of drought or threatened scarcity. During the nineties in California (USA), there was abundant drought publicity and some evidence of palpable pressure for conservation. There is a real possibility that the social desire for water conservation practices has inflated the figures (Berk et al., 1993).

The findings of the present literature review are summarized in Table 3.

\subsection{Intention - behavior gaps}

A common approach to promoting water conservation is providing information to the users about water deficiencies and motivating them to save water by explicit water-saving advise (Seyranian et al., 2015). Through information provision, water authorities assume there is some kind of knowledge deficit. Communication and information provision are regularly carried out through leaflets and flyers containing relevant data and indoor and outdoor water saving tips, with inclusive messages through different communication channels (Dolnicar et al., 2012; Kurz et al., 2005; Seyranian et al., 2015) ${ }^{10}$.

In dealing with the curbing of domestic water demand, managers should bear in mind that users may have different reactions when exposed to water policy information. In some occasions, indeed, people respond reactively instead of proactively (Beal et al., 2013; Sharp, 2006). Thus, it is important to know how people process their understanding of initiatives and policies (Sharp, 2006), among other reasons because there is nothing like straightforward implementation of recommended water rates, conservation practices or water saving behaviors.

The ultimate intention underlying information provision, proenvironmental strategies and water conservation campaigns (which are still in use by water companies and local authorities) is to reduce knowledge gaps about water consumption and conservation (Schultz, 2002; Seyranian et al., 2015). The overarching assumption is that once these knowledge gaps are resolved, water users will consequently implement saving practices (Seyranian et al., 2015).

Individuals engaged in pro-environmental attitudes attempt to affect the environmental resources as little as they can, or even better, they try to favor them (Steg and Vlek, 2009). One of the most common methodologies to understand the associations between intention, environmental behavior and resource conservation is the Theory of Planed Behavior (TPB), ${ }^{11}$ which states that the intentions resulting from a stimulus to adopt an action are the most direct explanatory variable of the observed behavior (Clark and Finley, 2007; Fielding et al., 2012). This theory has been used to predict people's intention to get involved in water conservation. When individuals are inclined to water saving, they usually acknowledge that water resources are valuable, understand saving as a moral need, and are capable of adopting efficient water-use behaviors (Pearce et al., 2014).

In some situations, individual users engage in proenvironmental behavior considering that it positively benefits them (Lindenberg and Steg, 2007). Notwithstanding, this argument might be contradicted by the fact that free riders also know that

\footnotetext{
10 (Dolnicar et al., 2012) suggest that in Australia, since people who already engage in water conservation behaviors tend to watch less TV and read more newspapers, TV would be a good communication channel for reaching those whose water conservation behaviors could be improved. For Perth, Western Australia Neither information leaflets nor socially comparative feedback produced significant reductions in water use, compared to controls (Kurz et al., 2005).

11 The TPB encompasses three explanatory behavioral variables: the attitude towards the behavior $(A C T)$, subjective norm $(\mathrm{SN})$, and perceived behavioral control (PBC) (Ajzen, 1991).
} 
Table 3

Mechanisms of self-reported water saving inflation.

\begin{tabular}{|c|c|}
\hline Mechanisms found in the literature & Country/region \\
\hline Underreporting related to social desirability (Beal et al., 2013). & California, USA \\
\hline Most consumers underestimate their water consumption (Fan et al., 2013). & China \\
\hline Motivations to engage in conservation when it is perceived as socially desirable or as a common (Cialdini et al., 2006; cited in Schultz et al., 2014). & Arizona, USA. \\
\hline Low correlation between self-reported and observed behavior (Corral-Verdugo, 1997) cited in (Steg and Vlek, 2009). & Mexico \\
\hline Social desirability of water conservation and inflation of figures (Berk et al., 1993). & California, USA \\
\hline Socially desirable habits are more likely to be overreported by households (Millock and Nauges, 2010). & OECD countries \\
\hline As to reported consumption behavior, there is no full agreement between attitudes and preferences (De Oliver, 1999). & $\begin{array}{l}\text { San Antonio, Texas, } \\
\text { USA }\end{array}$ \\
\hline If water users are unaware of the amount of water they are using, pricing controls may well be meaningless (Randolph an & Sidney, Australia \\
\hline
\end{tabular}

conservation is good for them, but do not contribute to it because they benefit on the effort of others (Gächter, 2007; Ostrom et al., 1999).

The advocates of the TPB argue that a behavioral intention is the closest explanatory variable of its execution (Landon et al., 2016). However, there are few researchers analyzing these connections and, in fact, they have found quite weak interactions between intent and observed behavior (Gregory and Di Leo, 2003; Landon et al., 2016).

Landon et al. (2016) examined water use attitudes towards conforming with a swaying water saving platform in College Station, Texas - USA. Although behavioral control was postulated to have a direct effect on behavior, they did not find any support for that relation. In Bulgaria, despite the fact that residents exhibited positive perceptions on water value and, consequently, some kind of intention to conserve it, the promotion of this behavior proved ineffective (Clark and Finley, 2007).

On the other hand, an assessment of the effect of proenvironmental identity in Italy provided support to the TPB (Carfora et al., 2017). Similar results were found for South Africa in the sense that positive attitudes towards water saving were associated to robust intentions to engage in expected actions (Onyenankeya et al., 2018). In the context of water conservation in Iran, Yazdanpanah et al., (2014) suggest that looming water crises, risk perception and self-rewarding sentiments raise the intention to save the water resource.

In a case study in Reno, Nevada - USA, people with similar current and past pro-environmental valuations were found to be more inclined to positively react to water saving programs (Trumbo \& O'Keefe, 2005). This case reveals a key element in explaining intent and actual engagement with water conservation, which is previous knowledge and awareness about the value of this utility. In this case, we suggest it is not possible to draw conclusions about the effect of information on water conservation behavior because there is a positive bias in the individuals who already know and practice conservation.

The analysis of the links between water conservation intention and actual pro-environmental behavior are summarized in Table 4. In this table cross-country evidence of intention - behavior gaps is presented.

Affluent families with high educational levels in Spain and California have been found to be more inclined to install watersaving equipment at home ${ }^{12}$ (Berk et al., 1993; MartínezEspiñeira and García-Valiñas, 2013). Low-income families, i.e., those characterized by a low water use baseline, tend to be more conscious of water conservation issues and seem to have robust

\footnotetext{
$\overline{12}$ Examples of water-saving equipment include water-saving technologies, including water-efficient washing machines and showerheads, as well as dual = flush toilets (Martínez-Espiñeira and García-Valiñas, 2013); low flow showerheads and low volume toilet (Dupont and Renzetti, 2013).
}

water saving routines (Gregory and Di Leo, 2003; MartínezEspiñeira and García-Valiñas, 2013). In terms of gender, water conservation habits and pro-environmental behavior, women are more prone to preserve the resource (Olli et al., 2001; Şener and Hazer, 2008).

The behavior of others appears as a barrier in effectively converting intentions into water saving behaviors. When a person is engaged in saving water, only if other family members are also engaged, that individual's actions will lead to water reduction at home (Fielding et al., 2012).

Water-usage habits (e.g., daily use of washing machine, hair washing and longer showers promoted by the media) constitute another barrier opposing conservation strategies (Fielding et al., 2012; Watson, 2017). Habits are mostly measured as behaviors adopted in the past (Fielding et al., 2012; Gregory and Di Leo, 2003) and intentions to conserve are measured through qualitative (e.g., Likert) scales (Clark and Finley, 2007; Millock and Nauges, 2010; Şener and Hazer, 2008). ${ }^{13}$

When pro-environmental behavior is associated to morals, difficult implementation processes and some degree of individual sacrifice, people are less prone to commit to saving. (Gilg and Barr, 2006; Lindenberg and Steg, 2007). Positive engagement takes place when consumers foresee positive consequences for them (Lindenberg and Steg, 2007).

Different authors have provided evidence and insight into understanding the effects of norms, normative social influence and normative appeals in water conservation (Bernedo et al., 2014; Corral-Verdugo and Frías-Armenta, 2006; Landon et al., 2018; Lindenberg and Steg, 2007).

Normative instructions advise on the amount of water people should consume (Landon et al., 2018). They are important when it comes to pro-environmental behavior, in the sense that it connects to what is right or wrong with respect to the environment (Lindenberg and Steg, 2007).

An important aspect of normative and social comparisons has to do with the risk posed by a high water consumption level that performs as a reference between relatively heavy and frugal consumers. When a social norm is not very demanding, it is convenient to encourage real conservation. Notwithstanding, when a social group has elevated average consumption levels, weak norms may induce those who were formerly below the average to increase consumption.

In College Station - Texas (USA), families belonging to the upper

\footnotetext{
13 (Clark and Finley, 2007) asked respondents to indicate how likely (on a 5-point Likert scale from very unlikely to very likely) they were to adopt the water saving activities during the coming year to examine determinants of intention to conserve water among residents of Blagoevgrad, Bulgaria. Millock and Nauges (2010) implemented a survey in OECD countries which included questions about households' attitudinal and behavioral factors measured on a 5-point Likert scale. In Turkey (Şener and Hazer, 2008), asked respondents could score 1, 2 or 3 on the three-point scales of the importance of values.
} 
Table 4

Mechanisms involved in the intention - behavior gap.

\begin{tabular}{|c|c|}
\hline Mechanisms found in the literature & Country/region \\
\hline The relations between intention and observed behavior are weak (Landon et al., 2016). & Texas - USA \\
\hline Dwellers exhibiting affirmative attitudes not necessarily reveal the same positive behavior (Jorgensen et al., 2009). & Australia \\
\hline Lack of consistency between general attitudes and conservation behavior (Gregory and Di Leo, 2003). & $\begin{array}{l}\text { New South Wales, } \\
\text { Australia. }\end{array}$ \\
\hline Pro-environmental attitudes do not translate into corresponding behavior (Berenguer et al., 2005) cited in (Pearce et al., 2014) & Australia \\
\hline Awareness of scarcity and restrictions observed in connection with unaltered consumption behaviors (Pearce et al., 2014). & Australia \\
\hline Link between intention and observed/actual behavior is fragile (Gregory and Di Leo, 2003) & $\begin{array}{l}\text { New South Wales, } \\
\text { Australia. }\end{array}$ \\
\hline $\begin{array}{l}\text { Dwellers exhibited positive perceptions of water value, which, however, were not effective within a water conservation strategy (Clark and } \\
\text { Finley, 2007) }\end{array}$ & Blagoevgrad, Bulgaria \\
\hline Low correlations between self-reported and observed behavior (Corral-Verdugo, 1997) & Mexico \\
\hline $\begin{array}{l}\text { Although knowing the problems of scarcity of water and corresponding restrictions, water guzzlers did not massively modify consumption } \\
\text { behaviors (Pearce et al., 2014). }\end{array}$ & Australia \\
\hline Positive attitudes and willingness to save water favor individual intentions to engage in water saving actions (Onyenankeya et al., 2018). & $\begin{array}{l}\text { Cape Town - South } \\
\text { Africa }\end{array}$ \\
\hline
\end{tabular}

$30 \%$ of the water consumer range reacted notably to a conservation intervention by decreasing the monthly average water use to 2659 gallons. Normative comparisons ${ }^{14}$ have proved effective in influencing a shift in familiy water use, when compared to a pseudo control (Landon et al., 2018). In California (USA), urban dwellers who were exposed to normative figures tended to use less water than a randomly selected comparison group (Schultz et al., 2014).

Research conducted in Mexico provides evidence that normative views about water conservation positively impact observed pro-environmental behavior, especially when people consider that water wasters or polluters should be punished (Corral-Verdugo and Frías-Armenta, 2006). In attempting to predict people's intention to conserve water in Taiwan (China), Lam (2006) concluded that attitudes and subjective norms altogether influenced the intention to retrofit. Consequently, normative goal-frames can be said to work better when individuals are conscious of environmental issues, which certainly rises the probability to engage in this type of behavior (Lindenberg and Steg, 2007).

In Iran, a group of farmers were classified as users of new and traditional water use schemes, the latter exhibiting lower normative proclivity than the new adopters (Yazdanpanah et al., 2014). After informative communication provision, a group of Israely households revealed $7.6 \%$ less water consumption with respect to reference households. This represented savings of around 1.2 cubic meter per family for a perod of five-weeks (Katz et al., 2016).

In a deeper analysis in New South Wales, Australia, Liu et al. (2015) analyzed the type of normative feedback preferred by water users. This study raises attention to the need to understand not simply the information feedback provided to households, but the way these consumers prefer this information. In situations of normative contrasts, local benchmarks have been compared to complementary benchmarking (Liu et al., 2015). The results indicate that water users seem to be less interested in knowing about water use at national or regional levels than at neighboring levels.

Results obtained in both developing and wealthier countries suggest that normative information, when presented in the form of comparative comments, might be more efficient than the provision of technical information only (Ferraro and Price, 2013; Seyranian et al., 2015). However, the success of these normative messages has been found to decline over time (Ferraro and Price, 2013; Fielding et al., 2013; Lindenberg and Steg, 2007).

In a deeper discussion regarding goal-frames, Lindenberg and Steg (2007) argue that individuals are more willing to perform

\footnotetext{
14 Specifically, the program provided water users with information regarding their outdoor water use (compared to an efficient standard) and their neighbors'.
}

pro-environmentally when a normative ${ }^{15}$ goal or target frame can be robustly sustained instead of hedonic or gain goals. In the cases studied by the mentioned authors, gain ${ }^{16}$ and hedonic ${ }^{17}$ goalframes referred to personal interests. In contrast, a normative goal-frame entails collective and environmental interests (Lindenberg and Steg, 2007).

The results of the above-mentioned works regarding the effectiveness of normative frames and the deterioration of saving behavior, call for further research and analysis to understand how to successfully design stable water saving strategies. Recent evaluations of behavioral shifting strategies, show the presence of 'intention-behavior gaps' (Novak et al., 2018). This is a key finding in the understanding of the strategies to promote water conservation, because intentions are not enough in seeking conservation behavior among household residents.

This notion is supported by research work performed since the first decade of the XXI century. Gregory and Di Leo (2003) concluded that there is no consistency between general attitudes and predicted conservation behavior. Clark and Finley (2007) found that residents in Bulgaria have positive attitudes toward water conservation but feel ineffectual in applying water conservation measures. After conducting research in Australia, Jorgensen et al. (2009) and Pearce et al. (2014) argue that awareness of scarcity and consequent restrictions are not altering consumption behaviors. Therefore, residents with positive attitudes may not always exhibit positive behavior. In Texas - USA, attitudes and subjective normative beliefs have not shown direct relationship with behavior (Landon et al., 2016).

Sustainable water conservation needs may remain unattended if we focus on the intention - behavior gaps. Defining 'behavior' as observed or reported actions when discussing about people's water consumption (Randolph and Troy, 2008) is not enough, since the evidence falls short to demonstrate that intentions are concretely converted into actions. In fact, not all households interested in conserving water report corresponding actions (Liu et al., 2015; Randolph and Troy, 2008).

Sustainability requires further aspirations than short-term

\footnotetext{
15 A normative goal frame activates all sorts of sub-goals associated to appropriateness such as behaving the right way, contributing to a clean environment, and showing exemplary behavior. They make people especially sensitive to what they think they ought to do (Lindenberg and Steg, 2007).

16 A gain-goal frame refers to shifting people's personal asset endowment (Lindenberg and Steg, 2007).

17 A hedonic-goal frame mobilizes several subgoals connected to the possibility to rise or expand the way an individual feels in a particular situation. For instance, avoiding pain or effort (Lindenberg and Steg, 2007).
} 
water consumption reduction by households. The long-term challenges of sustainability require the understanding of intention behavior - stable reduction gaps (see Fig. 4). Steady reductions reveal real pro-environmental behavior achievements of a whole water management system. In it, water users embed sustainable habits of water consumption into specific saving targets (Olmstead and Stavins, 2009; Steg and Vlek, 2009).

Illustration 2-2 shows three different water consumption levels. The first one corresponds to the observed consumption behavior prior to intervention, to which households are accustomed. Once pro-environmental behavior is campaigned, people usually reduce water consumption to a level which, although lower than the prior one, is not steadily maintained. This is so because intention is hardly converted into sustainable action, no matter if it initially turns into observed reductions, because it actually tends to wane through time (see section 2.5 below). The third level refers to stable reduction in water consumption, which should be the main focus of the sustainability analysis of urban water consumption. Thus, one question arises on how to design policy interventions to achieve stable water consumption reductions on the side of households? This question opens the door to an emerging field of analysis related to behavioral transitions to sustainability. This is especially important for initiatives aimed at accelerating the transition to sustainable cities in terms of its water management systems. Transitions framework proposed by (Brown et al., 2009) in regard of sustainability of water in cities, reveals promising tools to assist water strategist in identifying the attributes of more sustainable city states. Notwithstanding, cultural aspects of transitions, go beyond institutional arrangements and regulatory frameworks; social and behavioral dimensions should not be overlooked in this transitioning.

\subsection{Weakening of water reductions}

Pricing and water restraints are well recognized as water consumption regulators in periods of acute scarcity. However, there is no concluding evidence on the effect of this type of approach once the supply of water upsurges and scarcity is gone (Jorgensen et al., 2009), or when prices are reduced to pre-shortage levels.

The concluding statement about the short-term effect of water saving programs around the world is that water conservation gains tend to be ephemeral or reverted to pre-intervention consumption levels (Fielding et al., 2013; Lindenberg and Steg, 2007). This reversion effect has come to be called "intention - behavior gap" (Novak et al., 2018), due to the fact that intention falls short to maintain conservation behavior among household residents. In Illustration 2-3 an open loop is perceived in respect of the high levels of water consumption observed in households despite rules and regulations are put in place, and similarly when water conservation campaigns cease. This loop seems to be dominated by a memory in which habits and vain policy efforts are not be able to lead to expected steady reductions in water consumption behaviors.

Part of the current debate on price and non-price strategies rests upon the time span of policy measures. While extensive environmental programs (which are implemented as short-term responses to water crises) may influence behavior, this is probably not realistic for municipalities intending to attain sustainable demand reductions (Berk et al., 1993; Dolnicar et al., 2012; Seyranian et al., 2015). However, said short-term interventions constitute a common practice during droughts.

Between 1986 and 1991, California's longest water scarcity to date led to a vivid consumption reduction on the part of the population (Berk et al., 1993). Yet, this was influenced by strong advertising and conservation pressures during the drought, which, however, were weakened during the wet weather period (Berk et al., 1993; Maggioni, 2015). In South-Eastern Australia, Aisbett \& Steinhauser (2014) studied the effect of shifting water stock availability for urban use in situations of persistent drought. The results revealed that a $10 \%$ reduction in dam availability activated a deliberate saving of approximately 5.5\% throughout the water scarcity period. Similar results were found in Atlanta (USA), where the water authorities implemented an objective domiciliary messaging operation during the 2007 drought. In this case, normative pleas had an intense saving effect on water consumption during the first few days, to decline by approximately 50\% during the first year after the intervention (Bernedo et al., 2014). In the case of the drought that lasted for 12 years in different parts of Victoria (South-Eastern Australia), the restraints imposed by the authorities were perceived as a short-term response to counterbalance limited-supply and increasing-demand (Dolnicar et al., 2012). Results obtained in Switzerland, Spain, Queensland

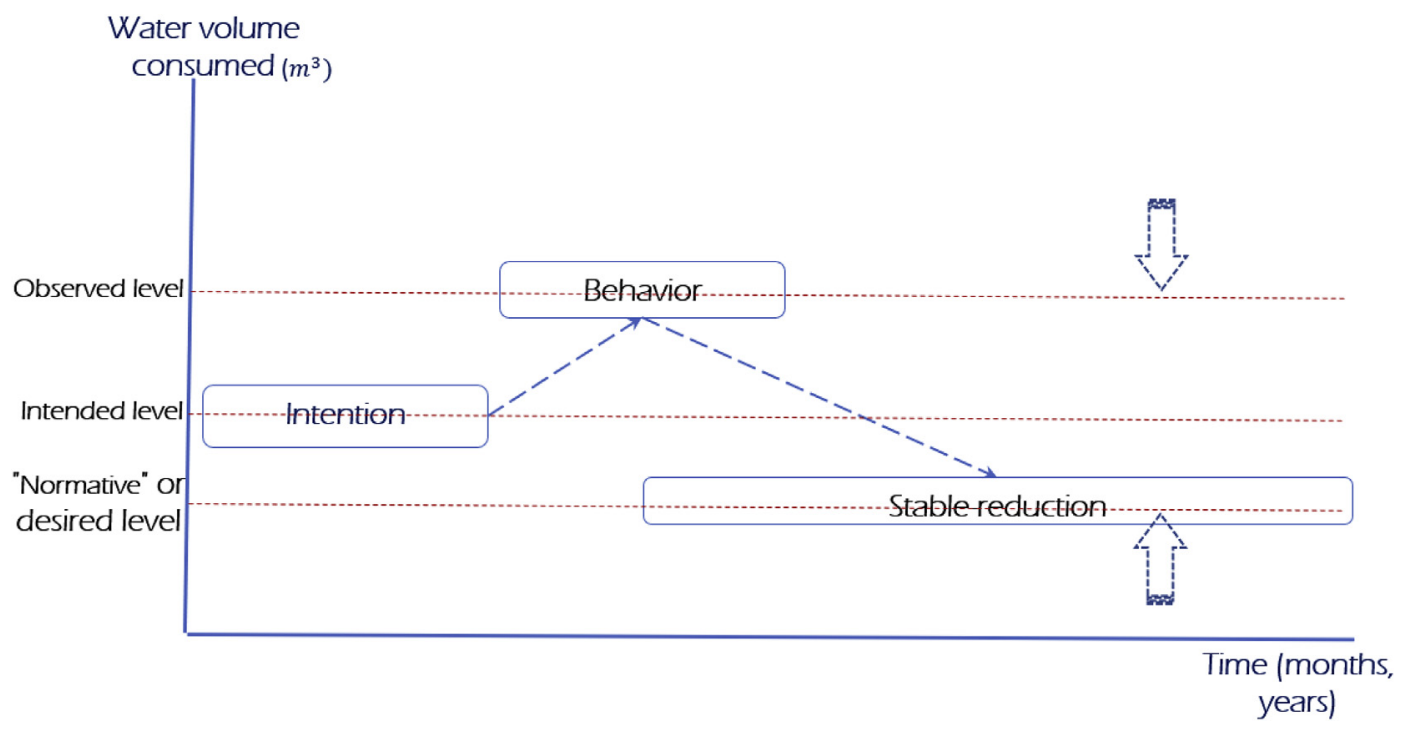

Illustration 2-2. Intention - behavior - stable reductions gap.

Source: author's elaboration 


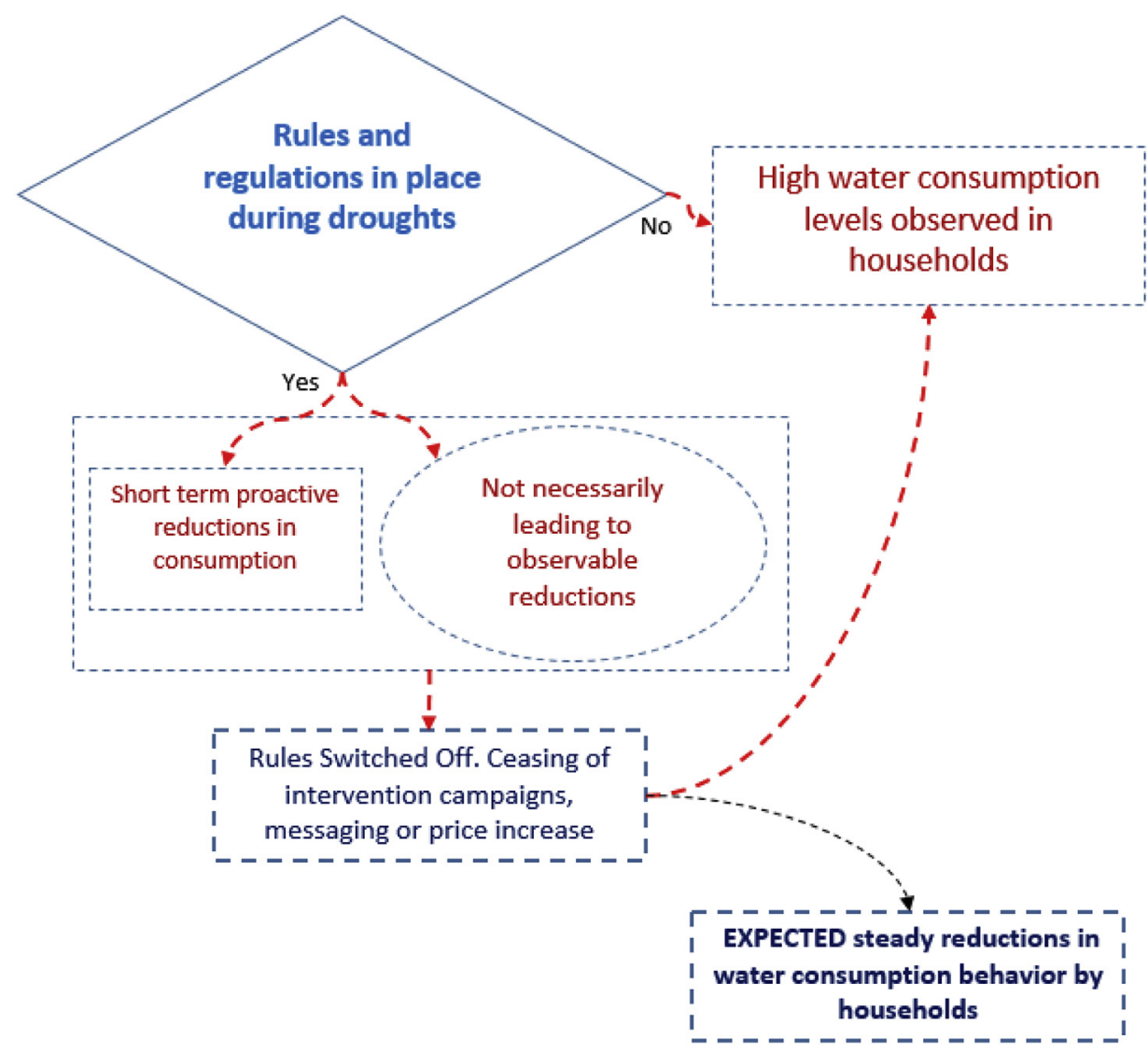

Illustration 2-3. Open loop around high levels of water consumption observed in households in presence of rules and campaigns.

Source: author's elaboration

(Australia), Israel, Mexico and California reveal how water use reductions tend to dissipate or revert to pre-shortage periods (Beal et al., 2013; Katz et al., 2016; Lindenberg and Steg, 2007; Novak et al., 2018), as it is described in Table 5.

A partial general conclusion suggests that if water consumption reductions tend to decrease after interventions cease, these should last for longer or become part of long-lasting programs.

The call for longer and more intense interventions implies the need to repeatedly inform the households. In providing more consumption and social norm information feedback to consumers in different formats, it is assumed that people will accumulate knowledge and be more acquainted and aware of the real importance of conservation, thus adopting sustainable attitudes and behaviors (Seyranian et al., 2015; Willis et al., 2011).
Notwitstanding, a crucial challenge for this assumption rests upon intriguing findings. Households with better knowledge about water conservation and more pro-environmental personal norms have shown relatively little response to normative feedback when compared to those with more relaxed personal norms (Schultz et al., 2014). This might be explained by the decreasing marginal effect of information provision according to prior knowledge level. The association between information provision and water consumption reduction through time might exhibit a decreasing pattern. This brings out the need to analyze the frequency and type of information provided to people with varying degrees of knowledge on water conservation.

Illustration 2-4presents a summary of the social dimensions that explain water conservation behavior. The first category of

Table 5

Mechanisms associated to fading water consumption reductions.

\begin{tabular}{|c|c|}
\hline Mechanisms found in the literature & Country/region \\
\hline Individuals are likely to return to prior attitude once the (dis)incentives come to an end (Lindenberg and Steg, 2007). & Different studies \\
\hline Possible rebound effect after the intervention (Novak et al., 2018) & $\begin{array}{l}\text { Switzerland and } \\
\text { Spain }\end{array}$ \\
\hline Conservation gains tend to be ephemeral (Fielding et al., 2013). & $\begin{array}{l}\text { Queensland, } \\
\text { Australia }\end{array}$ \\
\hline Water use reduction dissipates (Fielding et al., 2013) & $\begin{array}{l}\text { Queensland, } \\
\text { Australia }\end{array}$ \\
\hline Ceasing interventions return water usage to previous levels (Fielding et al., 2013) & $\begin{array}{l}\text { Queensland, } \\
\text { Australia }\end{array}$ \\
\hline $\begin{array}{l}\text { An approximate } 50 \% \text { reduction was observed } 1 \text { year after intervention. This confers an important role to short-lived behavioral adjustments that wane } \\
\text { rapidly (Bernedo et al., 2014). }\end{array}$ & Atlanta - USA \\
\hline Price increases may be effective in achieving water conservation, but are unlikely to have a long-term effect if the price is lowered (Katz et al., 2016). & Israel \\
\hline
\end{tabular}




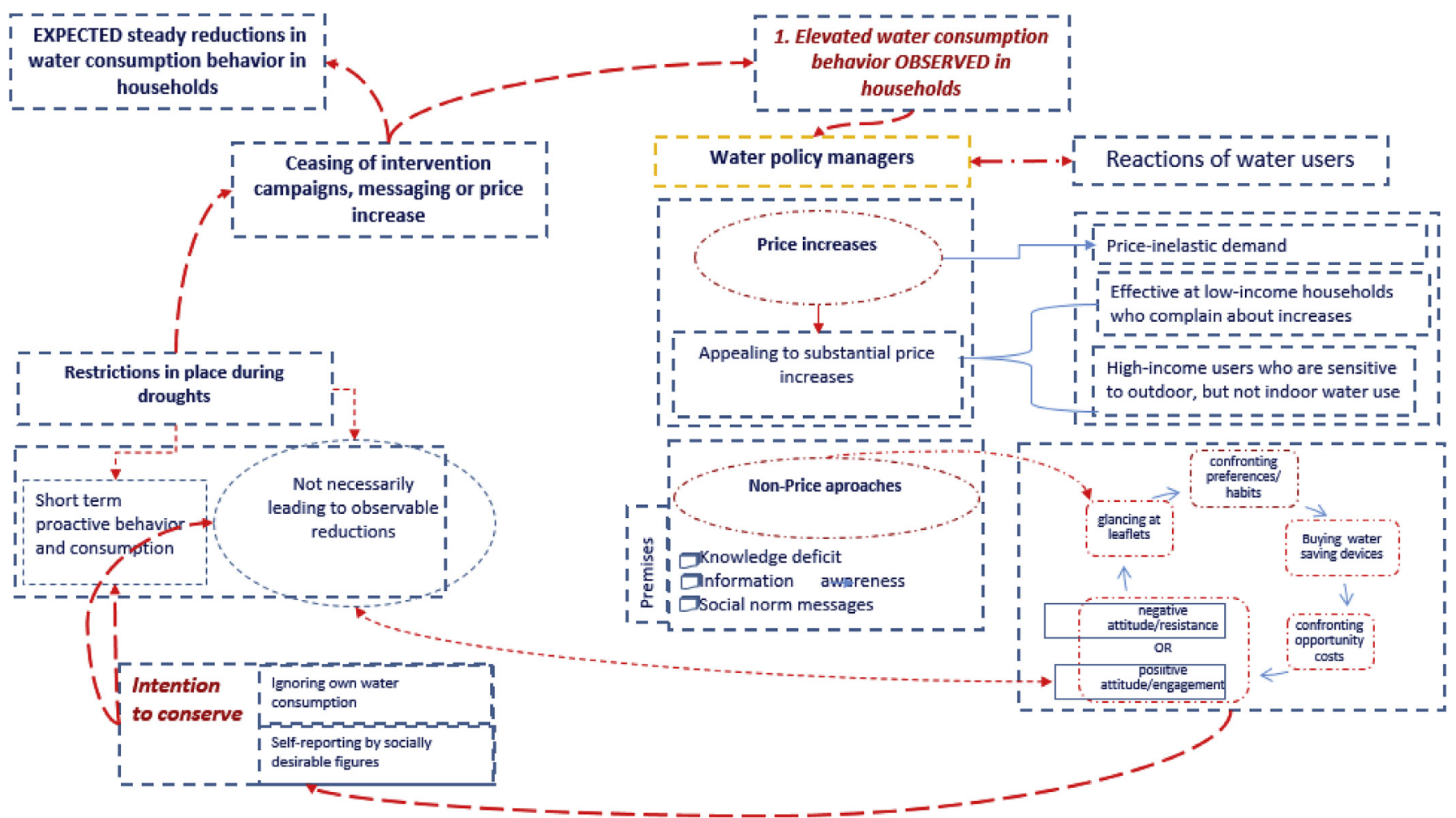

Illustration 2-4. The social dimensions of urban water conservation.

Source: author's elaboration

analysis (IWA, 2016) reveals excesive water consumption around the world. While the UN recommend a minimum availability of 50 lt/person/day, some regions consume up to $600 \mathrm{lt} /$ person/day.

\section{Discussion}

Upon growing water demand, climate change, drought conditions and water quality issues are exacerbating the risks of running out of water in different regions (Abdulrazzak and Khan, 1990; Balling et al., 2008). In response, policy makers tend to implement price and non-price approaches to promote water conservation (Millock and Nauges, 2010; Renwick et al., 1998).

Water price as policy mechanism to promote conservation depends on the different aspects of demand price-elasticity. Average water demand responses at the household level have been found to be relatively inelastic to price increase. As an alternative to drive water demand, non-price approaches appear as a combination of the social, psychological and other dimensions of demand.

Notwithstanding, non-price approaches do not actually trigger straightforward compliance on the part of water users. Once household members receive the conservation information, they do not act as passive recipients. Instead, different levels of consciousness activate corresponding reactions (Sharp, 2006). The key issue is a sort of iterative and continuous valuation by household members, who glance at leaflets (Kurz et al., 2005) and confront their own water allocation preferences (Bernedo et al., 2014; Olmstead and Stavins, 2009; Sharp, 2006) to their needs. In this way, they decide whether to buy water saving devices and afford the opportunity cost of allocating time to water saving (Russell et al., 2007; Martínez-Espiñeira and García-Valiñas, 2013; Millock and Nauges, 2010). As a result of this in-house process, household members decide whether they adopt a negative or positive attitude towards water conservation programs. Consequently, they either resist or engage, finally resulting in what has come to be called the intention to conserve (Clark and Finley, 2007; Lam, 2006; Trumbo \& O'Keefe, 2005).

However, this intention to conserve is characterized by two factors: People tend to ignore their own water consumption and to report socially desirable figures about it (Beal et al., 2013; Fan et al. 2013; Liu et al., 2016; Randolph and Troy, 2008). In response, policy makers and water managers provide contrasting feed-back about real consumption, together with normative and regulation news put in place during droughts.

In response to regulation, norms and rules, householders may or may not react through short term proactive behavior and consumption reduction. Since policies to manage water tend to focus on regulations for price and non-price approaches, an overarching aim of this article if to is to call the attention on the urgent need to provide empirical and theoretical evidence, to find out effective ways to accomplish Sustainable Development Goals (SDG) related to water use. The target goal 6.4, states that by 2030 water efficiency and sustainability in water withdrawals should be accomplished. More specifically target aims at "substantially increase water-use efficiency across all sectors and ensure sustainable withdrawals and supply of freshwater to address water scarcity and substantially reduce the number of people suffering from water scarcity". 18

The call I make to fulfil this SDG-6.4.-goal, refers to the need to not to largely focus on the supply side of the problem, but on the demand and behavioral side coming from surface and groundwater users. Despite of being a plausible SGD-goal, sustainable withdrawals, entails puzzling social dimensions, worth to incorporate in project designs and implementation. Behavioral and social

\footnotetext{
18 https://www.un.org/sustainabledevelopment/sustainable-development-goals/.
} 
dimensions, if left apart may put sustainability under risk; since as suggested by the evidence, once reductions in water consumption are observed, the gains use to vanish in the short term.

A general implication of fading proactive behavior after ceasing an intervention is that water conservation programs should probably be in place for longer periods of time. Nonetheless, the intensity or duration of the information and knowledge disseminated by authorities do not necessarily produce the stable adoption of conservation patterns. We argue on the likely existence of a decreasing marginal effect of water conservation information over time.

Although the brink of the state of the art ponders the existence of an intention - behavior gap, sustainability requires further aspirations than short-term water consumption reduction by households. The long-term challenges of sustainability require the understanding of 'intention - behavior - stable reduction' gaps.

Further research is needed to fill this double-gap. Studies aimed at understanding the drivers behind both the dissipation and stabilization of water consumption reduction through time are missing in the literature.

\section{Conclusions}

The present literature review is aimed at understanding the social and behavioral dimensions shaping urban water conservation attitudes. Strategies to curb water consumption patterns are related to technological advance, time allocation preferences regarding water saving patterns at the household level, and the implementation of home appliances. In most developed countries, smart metering, elaborated messaging and behavioral approaches are being tested. Notwithstanding, in both developing and developed countries, there is a behavioral regularity reflecting the presence of a gap between intention and effective behavior in conserving water in households.

Given the essential and public character of fresh water, policymakers have vast challenges to tackle this behavioral issue. There is need to continue exploring the complicated human dimensions of water consumption.

To reaffirm our understanding of the social dimensions of urban water saving patterns, we summarize the existence of five noteworthy social and behavioral issues. 1 . Price inelasticity of water demand leads to substantial price raising, which, in turn, is disapproved by water users. 2 . Regarding water saving devices, smart metering and household behavior, households tend to adopt consumption raising attitudes. 3. Inflation of self-reported water savings. Water conservation studies reveal the existence of discrepancies between three types of data regarding water consumption levels. First, real water consumption; second, the allegedly known household consumption level; and third, the desired consumption each household wants others know. 4. Intention behavior gaps related to the fact that, despite individuals' consciousness of the resource scarcity problem and their expressed intention to save water, the effective or real actions reveal a deviation from intention. 5. Water consumption reduction waning. The general evidence suggests that the observed reductions in water use tend to dissipate.

The evidence shows promising and worthy findings which should certainly encourage scholars and policymakers to continue discovering better ways to reach stable reductions in water consumption. However, it is important to take into consideration the role of other type of water users who similarly demand water in urban areas.

The present review is affected by different limitations. The possibility to summarize the quantitative effects of the implemented water saving strategies was limited. Provided that some good urban water conservation practices may have not been published in scientific journals, the sources of information to review the extant studies might be correspondingly limited.

\section{Appendix A. Supplementary data}

Supplementary data to this article can be found online at https://doi.org/10.1016/j.jclepro.2020.120895.

\section{References}

Abdulrazzak, M.J., Khan, M.Z.A., 1990. Domestic water conservation potential in Saudi Arabia. Environ. Manag. https://doi.org/10.1007/BF02394033.

Abrahamse, W., Steg, L., 2013. Social influence approaches to encourage resource conservation: a meta-analysis. Global Environ. Change. https://doi.org/10.1016/ j.gloenvcha.2013.07.029.

Aisbett, E., Steinhauser, R., 2014. Maintaining the common pool: voluntary water conservation in response to varying scarcity. Environ. Resour. Econ. https:// doi.org/10.1007/s10640-013-9722-3.

Ajzen, I., 1991. The theory of planned behavior. Organ. Behav. Hum. Decis. Process. https://doi.org/10.1016/0749-5978(91)90020-T.

Aprile, M.C., Fiorillo, D., 2017. Water conservation behavior and environmental concerns: evidence from a representative sample of Italian individuals. J. Clean. Prod. 159, 119-129. https://doi.org/10.1016/j.jclepro.2017.05.036.

Balling, R.C., Gober, P., Jones, N., 2008. Sensitivity of residential water consumption to variations in climate: an intraurban analysis of Phoenix, Arizona. Water Resour. Res. https://doi.org/10.1029/2007WR006722.

Beal, C.D., Stewart, R.A., Fielding, K., 2013. A novel mixed method smart metering approach to reconciling differences between perceived and actual residential end use water consumption. J. Clean. Prod. https://doi.org/10.1016/ j.jclepro.2011.09.007.

Berenguer, J., Corraliza, J.A., Martin, R., 2005. Rural-Urban differences in environmental concern, attitudes, and actions. Eur. J. Psychol. Assess. https://doi.org/ 10.1027/1015-5759.21.2.128.

Berk, R.A., Schulman, D., McKeever, M., Freeman, H.E., 1993. Measuring the impact of water conservation campaigns in California. Climatic Change. https://doi.org/ 10.1007/BF01091831.

Bernedo, M., Ferraro, P.J., Price, M., 2014. The persistent impacts of norm-based messaging and their implications for water conservation. J. Consum. Pol. https://doi.org/10.1007/s10603-014-9266-0.

Brown, R., Kneath, N., Wong, T., 2009. Urban water management in cities: historical, current and future regimes. Water Sci. Technol. IWA Publishing.

Carfora, V., Caso, D., Sparks, P., Conner, M., 2017. Moderating effects of proenvironmental self-identity on pro-environmental intentions and behaviour: a multi-behaviour study. J. Environ. Psychol. https://doi.org/10.1016/ j.jenvp.2017.07.001.

Chartzoulakis, K., Bertaki, M., 2015. Sustainable water management in agriculture under climate change. Agric. Agric. Sci. Procedia 4, 88-98. https://doi.org/ 10.1016/j.aaspro.2015.03.011.

Cialdini, R.B., Demaine, L.J., Sagarin, B.J., Barrett, D.W., Rhoads, K., Winter, P.L., 2006. Managing social norms for persuasive impact. Soc. Influ. https://doi.org/ 10.1080/15534510500181459.

Clark, W.A., Finley, J.C., 2007. Determinants of water conservation intention in Blagoevgrad, Bulgaria. Soc. Nat. Resour. https://doi.org/10.1080/ 08941920701216552.

Collinge, R.A., 1994. Transferable rate entitlements: the overlooked opportunity in municipal water pricing. Publ. Finance Rev. https://doi.org/10.1177/ 109114219402200103.

Corral-Verdugo, V., 1997. Dual "realities" of conservation behavior: self-reports vs observations of re-use and recycling behavior. J. Environ. Psychol. https:// doi.org/10.1006/jevp.1997.0048.

Corral-Verdugo, V., Frías-Armenta, M., 2006. Personal normative beliefs, antisocial behavior, and residential water conservation. Environ. Behav. https://doi.org/ $10.1177 / 0013916505282272$.

Corral-Verdugo, V., Frías-Armenta, M., Tapia-Fonllem, C.O., Fraijo-Sing, B.S., 2012 Protecting natural resources: psychological and contextual determinants of freshwater conservation. In: The Oxford Handbook of Environmental and Conservation Psychology. https://doi.org/10.1093/oxfordhb/ 9780199733026.013.0030.

De Oliver, M., 1999. Attitudes and inaction. A case study of the manifest demographics of urban water conservation. Environ. Behav. https://doi.org/ $10.1177 / 00139169921972155$

Dolnicar, S., Hurlimann, A., Grün, B., 2012. Water conservation behavior in Australia. J. Environ. Manag. https://doi.org/10.1016/j.jenvman.2012.03.042.

Dupont, D, Renzetti, S, 2013. Household behavior related to water conservation. Water Resour. Econ. 4

Fan, L., Liu, G., Wang, F., Geissen, V., Ritsema, C.J., Tong, Y., 2013. Water use patterns and conservation in households of Wei River Basin, China. Resour. Conserv. Recycl. https://doi.org/10.1016/j.resconrec.2013.02.017.

Ferraro, P.J., Price, M.K., 2013. Using nonpecuniary strategies to influence behavior: evidence from a large-scale field experiment. Rev. Econ. Stat. https://doi.org/ 
10.1162/REST_a_00344.

Fielding, K.S., Russell, S., Spinks, A., Mankad, A., 2012. Determinants of household water conservation: the role of demographic, infrastructure, behavior, and psychosocial variables. Water Resour. Res. https://doi.org/10.1029/ 2012WR012398.

Fielding, K.S., Spinks, A., Russell, S., McCrea, R., Stewart, R., Gardner, J., 2013. An experimental test of voluntary strategies to promote urban water demand management. J. Environ. Manag. https://doi.org/10.1016/j.jenvman.2012.10.027.

Gächter, S., 2007. Conditional cooperation : behavioral regularities from the lab and the field and their policy implications about the Centre or contact. Econ. Psycol Promising N. Cross-Disciplinary Field 19-50. April 2006(2006-3).

Gilg, A., Barr, S., 2006. Behavioural attitudes towards water saving? Evidence from a study of environmental actions. Ecol. Econ. https://doi.org/10.1016/ j.ecolecon.2005.04.010.

Grafton, R.Q., Ward, M.B., 2008. Prices versus rationing: marshallian surplus and mandatory water restrictions. Econ. Rec. https://doi.org/10.1111/j.14754932.2008.00483.x.

Gregory, G.D., Di Leo, M., 2003. Repeated behavior and environmental psychology: the role of personal involvement and habit formation in explaining water consumption. J. Appl. Soc. Psychol. https://doi.org/10.1111/j.15591816.2003.tb01949.x.

Harlan, S.L., Yabiku, S.T., Larsen, L., Brazel, A.J., 2009. Household water consumption in an arid city: affluence, affordance, and attitudes. Soc. Nat. Resour. https:// doi.org/10.1080/08941920802064679.

IWA, 2016. International Statistcs for Water Services.

Jehle, G., Reny, J., 2011. Advanced Microeconomic Theory (Third). Pearson, Essex.

Jorgensen, B., Graymore, M., O'Toole, K., 2009. Household water use behavior: an integrated model. J. Environ. Manag. 91 (1), 227-236. https://doi.org/10.1016/ j.jenvman.2009.08.009.

Katz, D., Grinstein, A., Kronrod, A., Nisan, U., 2016. Evaluating the effectiveness of a water conservation campaign: combining experimental and field methods. J. Environ. Manag. https://doi.org/10.1016/j.jenvman.2016.05.049.

Kurz, T., Donaghue, N., Walker, I., 2005. Utilizing a social-ecological framework to promote water and energy conservation: a field experiment. J. Appl. Soc. Psychol. https://doi.org/10.1111/j.1559-1816.2005.tb02171.x.

Lam, S.P., 2006. Predicting intention to save water: theory of planned behavior, response efficacy, vulnerability, and perceived efficiency of alternative solutions. J. Appl. Soc. Psychol. https://doi.org/10.1111/j.0021-9029.2006.00129.x.

Landon, A.C., Kyle, G.T., Kaiser, R.A., 2016. Predicting compliance with an information-based residential outdoor water conservation program. J. Hydrol https://doi.org/10.1016/j.jhydrol.2016.02.024.

Landon, A.C., Woodward, R.T., Kyle, G.T., Kaiser, R.A., 2018. Evaluating the efficacy of an information-based residential outdoor water conservation program. J. Clean. Prod. https://doi.org/10.1016/j.jclepro.2018.05.196.

Lindenberg, S., Steg, L., 2007. Normative, gain and hedonic goal frames guiding environmental behavior. J. Soc. Issues. https://doi.org/10.1111/j.15404560.2007.00499.x.

Liu, A., Giurco, D., Mukheibir, P., 2015. Motivating metrics for household water-use feedback. Resour. Conserv. Recycl. https://doi.org/10.1016/ j.resconrec.2015.05.008.

Liu, A., Giurco, D., Mukheibir, P., 2016. Urban water conservation through customised water and end-use information. J. Clean. Prod. https://doi.org/10.1016/ j.jclepro.2015.10.002.

Lowe, B., Lynch, D., Lowe, J., 2014. The role and application of social marketing in managing water consumption: a case study. Int. J. Nonprofit Voluntary Sect. Mark. https://doi.org/10.1002/nvsm.1484.

Maggioni, E., 2015. Water demand management in times of drought: what matters for water conservation. Water Resour. Res. https://doi.org/10.1002/ 2014WR016301.

Martínez-Espiñeira, R., García-Valiñas, M.Á., 2013. Adopting versus adapting: adoption of water-saving technology versus water conservation habits in Spain Int. J. Water Resour. Dev. https://doi.org/10.1080/07900627.2012.721695.

Millock, K., Nauges, C., 2010. Household adoption of water-efficient equipment: the role of socio-economic factors, environmental attitudes and policy. Environ. Resour. Econ. https://doi.org/10.1007/s10640-010-9360-y.

Nguyen, K.A., Stewart, R.A., Zhang, H., Sahin, O., Siriwardene, N., 2018. Re-engineering traditional urban water management practices with smart metering and informatics. Environ. Model. Software. https://doi.org/10.1016 j.envsoft 2017.12.015.

Novak, J., Melenhorst, M., Micheel, I., Pasini, C., Fraternali, P., Rizzoli, A.E., 2018. Integrating behavioural change and gamified incentive modelling for stimulating water saving. Environ. Model. Software. https://doi.org/10.1016/ j.envsoft.2017.11.038.

Nyamwanza, A.M., Kujinga, K.K., 2017. Climate change, sustainable water management and institutional adaptation in rural sub-Saharan Africa. Environ. Dev. Sustain. 19 (2), 693-706. https://doi.org/10.1007/s10668-016-9762-2.

Olli, E., Grendstad, G., Wollebaek, D., 2001. Correlates of environemental behaviors. Bringing back social context. Environ. Behav. https://doi.org/10.1177/ 00139160121972945.
Olmstead, S.M., Stavins, R.N., 2009. Comparing price and nonprice approaches to urban water conservation. Water Resour. Res. https://doi.org/10.1029/ 2008WR007227.

Onyenankeya, K., Caldwell, M., Okoh, A.I., 2018. Sustainable water use and the nexus of behavioural intentions: the case of four South African communities. Water Environ. J. https://doi.org/10.1111/wej.12326.

Ostrom, E., Burger, J., Field, C.B., Norgaard, R.B., Policansky, D., 1999. Revisiting the commons: local lessons, global challenges. Science 284 (5412), 278-282. https://doi.org/10.1126/science.284.5412.278.

Pearce, M., Willis, E., Mamerow, L., Jorgensen, B., Martin, J., 2014. The prestige of sustainable living: implications for water use in Australia. Geogr. J. https:// doi.org/10.1111/geoj.12016.

Randolph, B., Troy, P., 2008. Attitudes to conservation and water consumption. Environ. Sci. Pol. 11 (5), 441-455. https://doi.org/10.1016/j.envsci.2008.03.003.

Renwick, M.E., Archibald, S.O., A, S.O., 1998. Demand side management policies for residential water use: who bears the conservation demand side management policies for residential water. Source: Land Econ. https://doi.org/10.2307| 3147117.

Renwick, M.E., Green, R.D., 2000. Do residential water demand side management policies measure up? An analysis of eight California water agencies. J. Environ. Econ. Manag. https://doi.org/10.1007/978-81-322-2743-4_22.

Rodriguez-Sanchez, C., Schuitema, G., Claudy, M., Sancho-Esper, F., 2018. How trust and emotions influence policy acceptance: the case of the Irish water charges. Br. J. Soc. Psychol. https://doi.org/10.1111/bjso.12242.

Roibás, D., García-Valiñas, M.Á., Wall, A., 2007. Measuring welfare losses from interruption and pricing as responses to water shortages: an application to the case of Seville. Environ. Resour. Econ. https://doi.org/10.1007/s10640-0069072-5.

Russell, Clifford S., C, C.D., Schuck, E.C., 2007. Economic instruments for water management in the Middle East and North Africa. J. Water Resour. Dev. 23 (4), 659-677.

Salameh, E., 2008. Over-exploitation of groundwater resources and their environmental and socio-economic implications: the case of Jordan. Water Int. https:/ doi.org/10.1080/02508060801927663.

Schultz, P.W., 2002. Knowledge, information, and household recycling: examining the knowledge-deficit model of behavior change. In: New Tools for Environmental Protection: Education, Information, and Voluntary Measures. https:// doi.org/10.17226/10401.

Schultz, P.W., Messina, A., Tronu, G., Limas, E.F., Gupta, R., Estrada, M., 2014. Personalized normative feedback and the moderating role of personal norms: a field experiment to reduce residential water consumption. Environ. Behav. https://doi.org/10.1177/0013916514553835.

Sener, A., Hazer, O., 2008. Values and sustainable consumption behavior of women a Turkish sample. Sustain. Dev. https://doi.org/10.1002/sd.329.

Seyranian, V., Sinatra, G.M., Polikoff, M.S., 2015. Comparing communication strategies for reducing residential water consumption. J. Environ. Psychol. https:// doi.org/10.1016/j.jenvp.2014.11.009.

Sharp, L., 2006. Water demand management in England and wales: constructions of the domestic water user. J. Environ. Plann. Manag. https://doi.org/10.1080/ 09640560600946933

Spinti, J.E., St Hilaire, R., VanLeeuwen, D., 2004. Balancing landscape preferences and water conservation in a desert community. HortTechnology.

Steg, L., Vlek, C., 2009. Encouraging pro-environmental behaviour: an integrative review and research agenda. J. Environ. Psychol. https://doi.org/10.1016/ j.jenvp.2008.10.004.

Trumbo, C.W., O’Keefe, G.J., 2005. Intention to conserve water: environmental values, reasoned action, and information effects across time. Soc. Nat. Resour https://doi.org/10.1080/08941920590948002.

Van Vugt, M., 2001. Community identification moderating the impact of financial incentives in a natural social dilemma: water conservation. Pers. Soc. Psychol. Bull. https://doi.org/10.1177/01461672012711005.

Watson, S., 2017. Consuming water smartly: the significance of sociocultural differences to water-saving initiatives. Local Environ. https://doi.org/10.1080/ 13549839.2017.1334143.

Willis, R.M., Stewart, R.A., Panuwatwanich, K., Williams, P.R., Hollingsworth, A.L. 2011. Quantifying the influence of environmental and water conservation at titudes on household end use water consumption. J. Environ. Manag. https:// doi.org/10.1016/j.jenvman.2011.03.023.

World Bank, 2018. Water Scarce Cities: Thriving in a Finite World. International Bank for Reconstruction and Development.

Worthington, A.C., Hoffman, M., 2008. An empirical survey of residential water demand modelling. J. Econ. Surv. https://doi.org/10.1111/j.14676419.2008.00551.x.

Yazdanpanah, M., Hayati, D., Hochrainer-Stigler, S., Zamani, G.H., 2014. Understanding farmers' intention and behavior regarding water conservation in the Middle-East and North Africa: a case study in Iran. J. Environ. Manag. https:// doi.org/10.1016/j.jenvman.2014.01.016.

Zetland, D., 2011. The End of Abundance. Economic Solutions to Water Scarcity. Aguanomics Press, Amsterdam. 